\title{
Clinicopathological Comparison of Adenocarcinoma of Cervix and Endometrium Using Cell Cycle Markers: P16ink4a, P21waf1, and p27Kip1 on 132 Cancers
}

\author{
Farveen Marican Abu Backer, ${ }^{1}$ Nik Raihan Nik Mustapha, ${ }^{2}$ and Nor Hayati Othman' \\ ${ }^{1}$ Pathology Department, Hospital Universiti Sains Malaysia (HUSM), Kelantan, Malaysia \\ ${ }^{2}$ Pathology Department, Hospital Sultanah Bahiyah (HSB), Alor Star, Malaysia \\ Correspondence should be addressed to Nor Hayati Othman, hayati@kb.usm.my
}

Received 10 March 2011; Revised 9 June 2011; Accepted 14 August 2011

Academic Editor: Pierre Martin-Hirsch

Copyright (C) 2011 Farveen Marican Abu Backer et al. This is an open access article distributed under the Creative Commons Attribution License, which permits unrestricted use, distribution, and reproduction in any medium, provided the original work is properly cited.

\begin{abstract}
Objective. We studied the clinicopathological parameters of adenocarcinoma arising from endocervix (ECA) and from endometrium (EMA) based on the expression of P16ink4a, P21waf1, and p27Kip1 proteins. Study Design. Immunohistochemistry was done on sections of confirmed ECA and EMA from hysterectomy specimens which have had no prior chemotherapy/radiotherapy. Results. There were 40 ECAs and 92 EMAs. The mean age of ECA was 49.82 (SD 10.29); the youngest was 30 years old and the oldest 75 years old. The mean age of EMA was 54.45 (SD 10.92); the youngest was 30 years old and the oldest was 82 years old. For ECA, the size of the tumour is significantly associated with age and with depth of infiltration. FIGO stage is associated with histological grade. p21WAF1 expression is significantly associated with infiltration of the corpus and lymph node metastasis. p27Kip1 expression is significantly associated with lymph node invasion. The presence of lymph node metastasis is strongly associated when p16INK4a and p27Kip1 expressions are analyzed in combination. For EMA, p16INK4a expression is associated with histologic grade. Conclusion. Our study shows that we could use these cell cycle markers as predictors for more aggressive subsets of adenocarcinoma of the cervix and endometrium.
\end{abstract}

\section{Introduction}

The trend of adenocarcinoma of the cervix (ECA) is increasing [1-3] particularly among younger women [4]. Adenocarcinoma of the endometrium on the other hand affect older women, in the fifth to six decade [5]. In routine clinical practice, the presentation of these two cancers often overlap [6] and each requires different management [7]. ECA has more risk of recurrence [8] than endometrial adenocarcinoma. In Malaysia, adenocarcinoma of the cervix accounts for $5-15 \%$ of the total cervical cancers and the trend is also increasing [9]. The histological appearance of these two cancers under routine $\mathrm{H} / \mathrm{E}$ staining is almost similar in many instances. In a study on fractional curettage specimens from fifteen women who had tumours in the endocervical and endometrial specimens, only $34.1 \%$ were diagnosed as endometrial carcinomas [10]. Carcinoembryonic antigen (CEA), estrogen receptor
(ER), vimentin, and a panel of histochemical stains [11] are routinely used to differentiate these two cancers $[12,13]$. Routine IHC studies may not be helpful for synchronous endometrial and endocervical tumors [14]. In such, clonality studies using robust molecular techniques may help diagnose cases in which conventional imunohistochemical studies are not helpful [14].

p16INK4A is a molecular biomarker that consistently discriminates uterine cervix adenocarcinoma from endometrial adenocarcinoma [15]. It is a cell cycle regulatory tumour suppressor gene that has intimate interplay with the retinoblastoma gene [16]. p16INK4A could differentiate similar skin conditions: actinic keratosis from Bowens disease of which differentiating them before definitive treatment is important as each has different management [16]. p21WAF1 is a cyclin-dependent kinase inhibitor which acts as both a sensor and an effector of multiple antiproliferative signals 
[17]. p27Kip1 is a negative regulator of the G1 phase of the cell cycle [18]. Attempts at differentiating the clinicopathological parameters of adenocarcinoma of the cervix from endometrium have been done by a number of researchers using immunohistochemical stains $[13,14]$ and molecular techniques such as Western blotting [19] and PCR [20, 21]. Among the parameters studied was presence of estrogen receptor status $[19,22]$.

We studied the clinical parameters of adenocarcinomas arising from endocervix based on the expression of P16ink4a, P21waf1, and p27Kip1 proteins and whether the presence/ absence of such protein expression correlate with clinical presentations/behaviour of these cancers.

\section{Methodology}

This is a retrospective study on archived tissue blocks of histologically confirmed adenocarcinoma of the cervix and endometrium diagnosed from 2005 to 2008 . The samples were hysterectomy specimens with or without removal of ovaries and fallopian tubes. Biopsies (either colposcopic or by $\mathrm{cu}-$ rettage) were excluded. Specimens from patients who have had chemotherapy or radiotherapy before hysterectomy were excluded. These samples were taken from two public hospitals located in two different localities: Hospital Universiti Sains Malaysia (HUSM) (north-eastern region) and Hospital Sultanah Bahiyah (HSB) (north-western region of Malaysia).

The demography and the clinical details were obtained from the case folders. The histological diagnoses of ECA and EMA were categorized according to the main histological feature as endocervical NOS, adenosquamous, endometrioid, serous, and clear cell. The cancers are called "mixed" when the histological findings show more than one histological patterns. Immunohistochemistry staining was done on 4 micron thickness sections from paraffin blocks using the standard immunohistochemical staining technique. p16INK4a, P21WAF1, and P27Kip1 primary antibodies were at $1: 100$ dilutions. Positive controls were squamous cell carcinoma for p16INK4a, colonic adenocarcinoma for p21KIP1, and normal prostatic tissue for $\mathrm{p} 27 \mathrm{Kip} 1$ tissue as per suggestion by manufacturers of these antibodies. The association was determined using multiple logistic regression tests. The results were analysed using SPSS version 16, and the level of confidence ( $P$ value) was set at 0.05 .

The study was approved by the Research Ethics Committee of Universiti Sains Malaysia.

\section{Results}

There were 40 adenocarcinomas (ECAs) of the endocervix and 92 adenocarcinomas of the endometrium (EMAs). The median age for adenocarcinoma of the cervix was 48.5 years, and the mean age was 49.82 (SD 10.3). The youngest patient was 30 years old and the oldest 75 year old. The median age for adenocarcinoma of the endometrium was 55.0 years and the mean age was 54.45 (SD 10.9). The youngest patient was 30 years old and the oldest 82 years old. For adenocarcinoma of the cervix, there were $74 \%$ Malays, $18 \%$ Chinese, $8 \%$
TABLE 1: Summary of the clinicopathological parameters in adenocarcinoma of the cervix (ECA) and adenocarcinoma of the endometrium (EMA).

\begin{tabular}{|c|c|c|c|}
\hline Variables of ECA & $\begin{array}{c}\text { Frequency } \\
(\%) \text { of } \\
\text { ECA }\end{array}$ & Variables of EMA & $\begin{array}{c}\text { Frequency } \\
(\%) \text { of } \\
\text { EMA }\end{array}$ \\
\hline Age (years) & & Age (years) & \\
\hline$<35$ & $3(7.5)$ & $<50$ & $28(30.4)$ \\
\hline $35-54$ & $22(55.0)$ & $50-60$ & $35(38.0)$ \\
\hline$\geq 55$ & $15(37.5)$ & $>60$ & $29(31.5)$ \\
\hline FIGO stage & & FIGO stage & \\
\hline I & $27(57.5)$ & I & $50(54.3)$ \\
\hline 11 & $7(17.5)$ & II & $13(14.1)$ \\
\hline 111 & $5((12.5)$ & 111 & $13(14.1)$ \\
\hline IV & $5(12.5)$ & lV & $16(17.4)$ \\
\hline $\begin{array}{l}\text { Histology tumor } \\
\text { differentiation }\end{array}$ & & $\begin{array}{l}\text { Myometrial } \\
\text { invasion }\end{array}$ & \\
\hline Well/moderate & $25(62.5)$ & $<1 / 2$ & $45(48.9)$ \\
\hline Poor and Special type & $15(37.5)$ & $>1 / 2$ & $47(51.1)$ \\
\hline Infiltration depth & & Histologic grade & \\
\hline Inner $2 / 3$ & $13(32.5)$ & G1 & $39(42.4)$ \\
\hline \multirow[t]{2}{*}{ Outer $1 / 3$ or through } & $27(67.5)$ & G2 & $23(25.0)$ \\
\hline & & G3 & $30(32.6)$ \\
\hline Tumor length & & $\begin{array}{l}\text { Postmenopausal } \\
\text { status }\end{array}$ & \\
\hline$<20 \mathrm{~mm}$ & $11(32.5)$ & Yes & $54(58.7)$ \\
\hline$>20 \mathrm{~mm}$ & $29(67.5)$ & No & $38(41.3)$ \\
\hline \multicolumn{4}{|l|}{ Tumor thickness } \\
\hline$<5 \mathrm{~mm}$ & $4(10.0)$ & & \\
\hline$>5 \mathrm{~mm}$ & $36(90.0)$ & & \\
\hline \multicolumn{4}{|l|}{ Infiltration to corpus } \\
\hline Yes & $17(42.5)$ & & \\
\hline No & $23(57.5)$ & & \\
\hline \multicolumn{4}{|l|}{ Vascular invasion } \\
\hline Yes & $20(50.0)$ & & \\
\hline No & $20(50.0)$ & & \\
\hline \multicolumn{4}{|l|}{ Lymph node invasion } \\
\hline Yes & $12(30.0)$ & & \\
\hline No & $28(70.0)$ & & \\
\hline Histologic type: & & Histologic type: & \\
\hline Endocervical NOS & $25(62.5)$ & Endometrioid & $75(81.5)$ \\
\hline Adenosquamous & $6(15.0)$ & Adenosquamous & $4(4.4)$ \\
\hline Endometrioid & $5(12.5)$ & Clear cell & $5(5.4)$ \\
\hline Serous & $1(2.5)$ & Serous & $5(5.4)$ \\
\hline "Mixed" & $2(5.0)$ & "Mixed" & $3(3.3)$ \\
\hline
\end{tabular}

Siamese, and no Indian patients while for endometrial carcinoma, there were 79\% Malays, 11\% Chinese, 9\% Indian, and $1 \%$ Siamese ethnic group.

The most common histological type of adenocarcinoma of the cervix was mucinous type: $62.5 \%$ (25/40), and the commonest histological subtype of endometrial 
TABLE 2: Interrelationship* between clinicopathologic parameters in patients with adenocarcinoma of the cervix (ECA).

\begin{tabular}{|c|c|c|c|c|c|c|c|c|c|c|c|}
\hline & $\begin{array}{c}\text { Age } \\
\text { group } \\
(P \text { value })\end{array}$ & $\begin{array}{c}\text { Ethnic } \\
(P \text { value })\end{array}$ & $\begin{array}{l}\text { Diagnosis } \\
(P \text { value })\end{array}$ & $\begin{array}{c}\text { Histo } \\
\text { grade } \\
(P \text { value })\end{array}$ & $\begin{array}{c}\text { FIGO } \\
\text { stage } \\
(P \text { value })\end{array}$ & $\begin{array}{c}\text { Infiltration } \\
\text { depth } \\
(P \text { value })\end{array}$ & $\begin{array}{c}\text { Tumour } \\
\text { size } \\
(\text { diameter }) \\
(P \text { value })\end{array}$ & $\begin{array}{c}\text { Tumor } \\
\text { thickness } \\
(P \text { value })\end{array}$ & $\begin{array}{c}\text { Corpus } \\
\text { infiltra- } \\
\text { tion } \\
(P \text { value }) \\
\end{array}$ & $\begin{array}{l}\text { Vascular } \\
\text { invasion } \\
(P \text { value })\end{array}$ & $\begin{array}{c}\mathrm{LN} \\
\text { invasion } \\
(P \text { value })\end{array}$ \\
\hline Age group & - & 0.140 & 0.377 & 0.372 & 0.582 & 0.392 & 0.006 & 0.364 & 0.301 & 0.165 & 0.056 \\
\hline Ethnic & & - & 0.090 & 0.850 & 0.206 & 0.559 & 0.838 & 0.224 & 0.858 & 0.140 & 0.017 \\
\hline Histologic type & & & - & $<0.0001$ & 0.572 & 0.191 & 0.411 & 0.586 & 0.804 & 0.744 & 0.722 \\
\hline Histologic grade & & & & - & 0.090 & 0.542 & 0.120 & 0.586 & 0.680 & 0.102 & 0.012 \\
\hline FIGO stage & & & & & - & 0.330 & 0.152 & 1.000 & 0.042 & 0.003 & $<0.0001$ \\
\hline Infiltration depth & & & & & & - & 0.010 & 0.056 & 0.085 & 0.018 & 0.507 \\
\hline Tumor length & & & & & & & - & 0.025 & 0.230 & 0.013 & 0.076 \\
\hline Tumor thickness & & & & & & & & - & 0.749 & 0.292 & 0.818 \\
\hline Corpus infiltration & & & & & & & & & - & 0.337 & 0.043 \\
\hline Vascular invasion & & & & & & & & & & - & 0.038 \\
\hline LN invasion & & & & & & & & & & & - \\
\hline
\end{tabular}

${ }^{*}$ Calculated using Chi-square.

TABLE 3: Interrelationship* between clinicopathological parameters in patients with adenocarcinoma of endometrium (EMA).

\begin{tabular}{|c|c|c|c|c|c|c|c|}
\hline & $\begin{array}{c}\text { Age group } \\
(P \text { value })\end{array}$ & $\begin{array}{c}\text { Menopausal } \\
\text { status } \\
(P \text { value })\end{array}$ & $\begin{array}{c}\text { Ethnic } \\
(P \text { value })\end{array}$ & $\begin{array}{c}\text { Diagnosis } \\
(P \text { value })\end{array}$ & $\begin{array}{l}\text { Histology } \\
\text { grade } \\
(P \text { value })\end{array}$ & $\begin{array}{c}\text { Myometrial } \\
\text { invasion } \\
(P \text { value })\end{array}$ & $\begin{array}{l}\text { FIGO stage } \\
(P \text { value })\end{array}$ \\
\hline Age group & - & $<0.0001$ & 0.139 & 0.178 & 0.175 & 0.101 & 0.343 \\
\hline Meno status & - & - & 0.194 & 0.270 & 0.641 & 0.062 & 0.260 \\
\hline Ethnic & - & - & - & 0.825 & 0.703 & 0.248 & 0.026 \\
\hline Histologic type & - & - & - & - & $<0.0001$ & 0.213 & 0.081 \\
\hline Histologic grade & - & - & - & - & - & 0.060 & $<0.0001$ \\
\hline Myometrial invasion & - & - & - & - & - & - & $<0.0001$ \\
\hline FIGO stage & - & - & - & - & - & - & - \\
\hline
\end{tabular}

adenocarcinoma was endometrioid type (75/92). Majority of the patients were in FIGO stage I (ECA 57.5\%, EMA 54.3\%). The summary of the clinicopathological findings of the 132 cancers is in Table 1.

The interrelationship between the various clinicopathological correlations is as shown in Table 2 for ECA and Table 3 for EMA. For adenocarcinoma of the cervix, the grade was significantly associated with histologic type and with lymph node. The age of the patients was significantly associated with the size of the tumor. The tumor size is also associated with the depth of infiltration. FIGO stage is strongly associated with vascular and lymph node invasion (Table 2). For adenocarcinoma of the endometrium, FIGO stage is associated with histological grade and expectedly with myometrial invasion (Table 3).

For adenocarcinoma of the cervix, none of the clinicopathological parameters is significantly associated with p16INK4a expression (Table 4) including the histologic subtypes. p21WAF1 expression (Table 5) is significantly associated with infiltration of the corpus $(P=0.043)$ and lymph node metastasis $(P=0.071)$, and p27Kip1 expression (Table $6)$ is significantly associated with lymph node invasion $(P=$ $0.030)$. The presence of lymph node metastasis is strongly associated $(P=0.013)$ when p16INK4a and p27Kip1 expressions are analyzed in combination.

For adenocarcinoma of the endometrium, p16INK4a expression (Table 7) is associated with histologic grade $(P=$ $0.014)$ but not the histologic type $(P=0.888)$. p21WAF1 and $\mathrm{p} 27 \mathrm{Kip} 1 \mathrm{did}$ not show significant associations with clinicopathologic parameters $(P>0.05)$.

\section{Discussion}

Adenocarcinoma arising from the cervix and the endometrium in our series shows overlapping clinicopathological presentations. The youngest patients for both cancers were 30 years of age though the mean age of endocervical adenocarcinoma is about five years younger. There was a number of adenocarcinomas of the cervix which was in the mean age of adenocarcinoma of endometrium. These two cancers also have similar ethnic distribution. The ethnic distribution of our cases is comparable with the background population implying fair representation of the sampling population. They are more seen among the ethnic Malay than other ethnic groups in this series depicting the ethnic distributions of the community served by the two hospitals. 
TABle 4: Associations between p16INK4a expression and clinicopathologic parameter for endocervical adenocarcinoma.

\begin{tabular}{|c|c|c|c|c|}
\hline Characteristics & $\begin{array}{l}\text { No. of } \\
\text { patients }\end{array}$ & $\begin{array}{c}\text { Positive, } \\
n(\%) \\
(n=32)\end{array}$ & $\begin{array}{c}\text { Negative, } \\
n(\%) \\
(n=8) \\
\end{array}$ & $P$ value \\
\hline \multicolumn{5}{|l|}{ Age (years) } \\
\hline$<35$ & 3 & $2(66.7)$ & $1(33.3)$ & \multirow{3}{*}{0.256} \\
\hline $35-54$ & 22 & $16(72.7)$ & $6(27.3)$ & \\
\hline$\geq 55$ & 15 & $14(93.3)$ & $1(6.7)$ & \\
\hline \multicolumn{5}{|l|}{ FIGO stage } \\
\hline I-II & 30 & $24(80.0)$ & $6(20.0)$ & \multirow{2}{*}{1.000} \\
\hline III-IV & 10 & $8(80.0)$ & $2(20.0)$ & \\
\hline \multicolumn{5}{|l|}{$\begin{array}{l}\text { Histology tumor } \\
\text { differentiation }\end{array}$} \\
\hline Well/moderate & 25 & $18(72.0)$ & $7(28.0)$ & \multirow{2}{*}{0.102} \\
\hline Poor & 15 & $14(93.3)$ & $1(6.7)$ & \\
\hline \multicolumn{5}{|l|}{ Infiltration depth } \\
\hline Inner $2 / 3$ & 13 & $9(69.2)$ & $4(30.8)$ & \multirow{2}{*}{0.237} \\
\hline Outer $1 / 3$ or through & 27 & $23(85.2)$ & $4(14.8)$ & \\
\hline \multicolumn{5}{|l|}{ Tumor size ([diameter) } \\
\hline$<20 \mathrm{~mm}$ & 11 & $8(72.7)$ & $3(27.3)$ & \multirow{2}{*}{0.479} \\
\hline$>20 \mathrm{~mm}$ & 29 & $24(82.8)$ & $5(17.2)$ & \\
\hline \multicolumn{5}{|l|}{ Tumor thickness } \\
\hline$<5 \mathrm{~mm}$ & 4 & $3(75.0)$ & $1(25.0)$ & \multirow{2}{*}{0.792} \\
\hline$>5 \mathrm{~mm}$ & 36 & $29(80.6)$ & $7(19.4)$ & \\
\hline \multicolumn{5}{|l|}{ Infiltration to corpus } \\
\hline Yes & 17 & $13(76.5)$ & $4(23.5)$ & \multirow{2}{*}{0.631} \\
\hline No & 23 & $19(82.6)$ & $4(17.4)$ & \\
\hline \multicolumn{5}{|l|}{ Vascular invasion } \\
\hline Yes & 20 & $17(85.0)$ & $3(15.0)$ & \multirow{2}{*}{0.429} \\
\hline No & 20 & $15(75.0)$ & $5(25.0)$ & \\
\hline \multicolumn{5}{|l|}{ Lymph node invasion } \\
\hline Yes & 12 & $8(66.7)$ & $4(33.3)$ & \multirow{2}{*}{0.168} \\
\hline No & 28 & $24(85.7)$ & $4(14.3)$ & \\
\hline \multicolumn{5}{|l|}{ Histologic type } \\
\hline Endocervical & 25 & $20(80.0)$ & $5(20.0)$ & \multirow{2}{*}{1.000} \\
\hline Non endocervical & 15 & $12(80.0)$ & $3(20.0)$ & \\
\hline
\end{tabular}

We noted that certain clinicopathological parameters were significantly associated with other parameters within the same cancer. For adenocarcinoma of the cervix, the age of the patients was significantly associated with tumor size and with depth of infiltration. The histologic grade was strongly associated with presence of lymph node metastasis. FIGO staging was strongly associated with presence of corpus infiltration, vascular invasion, and lymph node metastasis. For adenocarcinoma of endometrium, the age of the patients was associated with menopausal status, FIGO staging with histological grading of the cancer, and presence/absence of myometrial invasion.

When these clinicopathological parameters were tested against the expression of the three cell cycle markers, none of the clinicopathological parameters of adenocarcinoma of
TABle 5: Associations between P21wafl expression and clinicopathologic parameter for adenocarcinoma of the cervix.

\begin{tabular}{|c|c|c|c|c|}
\hline Characteristics & $\begin{array}{c}\text { No. of } \\
\text { patients }\end{array}$ & $\begin{array}{c}\text { Positive, } \\
n(\%) \\
(n=28)\end{array}$ & $\begin{array}{c}\text { Negative, } \\
n(\%) \\
(n=12)\end{array}$ & $P$ value \\
\hline \multicolumn{5}{|l|}{ Age (years) } \\
\hline$<35$ & 3 & $2(66.7)$ & $1(33.3)$ & \multirow{3}{*}{0.937} \\
\hline $35-54$ & 22 & $15(68.1)$ & $7(31.8)$ & \\
\hline$\geq 55$ & 15 & $11(73.3)$ & $4(33.7)$ & \\
\hline \multicolumn{5}{|l|}{ FIGO stage } \\
\hline I-II & 30 & $23(76.7)$ & $7(23.3)$ & \multirow{2}{*}{0.111} \\
\hline III-IV & 10 & $5(50.0)$ & $5(50.0)$ & \\
\hline \multicolumn{5}{|l|}{$\begin{array}{l}\text { Histology tumor } \\
\text { differentiation }\end{array}$} \\
\hline Well/moderate & 25 & $16(64.0)$ & $9(36.0)$ & \multirow{2}{*}{0.285} \\
\hline Poor & 15 & $12(80.0)$ & $3(20.0)$ & \\
\hline \multicolumn{5}{|l|}{ Infiltration depth } \\
\hline Inner $2 / 3$ & 13 & $10(76.9)$ & $3(23.1)$ & \multirow{2}{*}{0.507} \\
\hline Outer $1 / 3$ or through & 27 & $18(66.7)$ & $9(33.3)$ & \\
\hline \multicolumn{5}{|l|}{ Tumor length } \\
\hline$<20 \mathrm{~mm}$ & 11 & $7(63.6)$ & $4(36.4)$ & \multirow{2}{*}{0.589} \\
\hline$>20 \mathrm{~mm}$ & 29 & $21(72.4)$ & $8(27.6)$ & \\
\hline \multicolumn{5}{|l|}{ Tumor thickness } \\
\hline$<5 \mathrm{~mm}$ & 4 & $1(25.0)$ & $3(75.0)$ & \multirow{2}{*}{0.101} \\
\hline$>5 \mathrm{~mm}$ & 36 & $27(75.0)$ & $9(25.0)$ & \\
\hline \multicolumn{5}{|l|}{ Infiltration to corpus } \\
\hline Yes & 17 & $9(52.9)$ & $8(47.1)$ & \multirow{2}{*}{0.043} \\
\hline No & 23 & $19(82.6)$ & $4(17.4)$ & \\
\hline \multicolumn{5}{|l|}{ Vascular invasion } \\
\hline Yes & 20 & $15(75.0)$ & $5(25.0)$ & \multirow{2}{*}{0.490} \\
\hline No & 20 & $13(65.0)$ & $7(35.0)$ & \\
\hline \multicolumn{5}{|l|}{ Lymph node invasion } \\
\hline Yes & 12 & $6(50.0)$ & $6(50.0)$ & \multirow{2}{*}{0.071} \\
\hline No & 28 & $22(78.6)$ & $6(21.4)$ & \\
\hline \multicolumn{5}{|l|}{ Histologic type } \\
\hline Endocervical & 25 & $17(68.0)$ & $8(32.0)$ & \multirow{2}{*}{0.722} \\
\hline Non endocervical & 15 & $11(73.3)$ & $4(26.7)$ & \\
\hline
\end{tabular}

the cervix including the histologic subtypes had significant association with p16INK4a expression alone. However, when p16INK4a expression and p27Kip1 expressions were analyzed in combination, there were strong associations with presence/absence of lymph node metastasis. p21WAF1 expression alone is significantly associated with infiltration of the corpus and lymph node metastasis. Lymph node involvement was also significantly associated with p27Kip1 expression. For adenocarcinoma of endometrium, only P16INK4a expression had strong association with the histologic grade. p21WAF1 and p27Kip1 expressions were not significantly associated with any clinicopathological parameters. Our study shows that we could use these cell cycle markers as predictors for more aggressive subsets of adenocarcinomas of the cervix and endometrium. 
TABle 6: Associations between p27Kip1 expression and clinicopathologic parameter for endocervical adenocarcinoma.

\begin{tabular}{|c|c|c|c|c|}
\hline Characteristics & $\begin{array}{l}\text { No. of } \\
\text { patients }\end{array}$ & $\begin{array}{c}\text { Positive, } \\
n(\%) \\
(n=17)\end{array}$ & $\begin{array}{c}\text { Negative, } \\
n(\%) \\
(n=23)\end{array}$ & $P$ value \\
\hline \multicolumn{5}{|l|}{ Age (years) } \\
\hline$<35$ & 3 & $2(66.7)$ & $1(33.3)$ & \multirow{3}{*}{0.292} \\
\hline $35-54$ & 22 & $7(31.8)$ & $15(68.2)$ & \\
\hline$\geq 55$ & 15 & $8(53.3)$ & $7(46.7)$ & \\
\hline \multicolumn{5}{|l|}{ FIGO stage } \\
\hline I-II & 30 & $15(50.0)$ & $15(50.0)$ & \multirow{2}{*}{0.097} \\
\hline III-IV & 10 & $2(20.0)$ & $8(80.0)$ & \\
\hline \multicolumn{5}{|l|}{$\begin{array}{l}\text { Histology tumor } \\
\text { differentiation }\end{array}$} \\
\hline Well/moderate & 25 & $11(44.0)$ & $14(56.0)$ & \multirow{2}{*}{0.804} \\
\hline Poor & 15 & $6(40.0)$ & $9(60.0)$ & \\
\hline \multicolumn{5}{|l|}{ Infiltration depth } \\
\hline Inner $2 / 3$ & 13 & $5(38.5)$ & $8(61.5)$ & \multirow{2}{*}{0.720} \\
\hline Outer $1 / 3$ or through & 27 & $12(44.4)$ & $15(55.6)$ & \\
\hline \multicolumn{5}{|l|}{ Tumor length } \\
\hline$<20 \mathrm{~mm}$ & 11 & $5(45.5)$ & $6(54.5)$ & \multirow{2}{*}{0.818} \\
\hline$>20 \mathrm{~mm}$ & 29 & $12(41.4)$ & $17(58.6)$ & \\
\hline \multicolumn{5}{|l|}{ Tumor thickness } \\
\hline$<5 \mathrm{~mm}$ & 4 & $1(25.0)$ & $3(75.0)$ & \multirow{2}{*}{0.395} \\
\hline$>5 \mathrm{~mm}$ & 36 & $16(44.4)$ & $20(55.6)$ & \\
\hline \multicolumn{5}{|l|}{ Infiltration to corpus } \\
\hline Yes & 17 & $6(35.3)$ & $11(64.7)$ & \multirow{2}{*}{0.428} \\
\hline No & 23 & $11(47.8)$ & $12(52.2)$ & \\
\hline \multicolumn{5}{|l|}{ Vascular invasion } \\
\hline Yes & 20 & $7(35.0)$ & $13(65.0)$ & \multirow{2}{*}{0.337} \\
\hline No & 20 & $10(50.0)$ & $10(50.0)$ & \\
\hline \multicolumn{5}{|l|}{ Lymph node invasion } \\
\hline Yes & 12 & $2(16.7)$ & $10(83.3)$ & \multirow{2}{*}{0.030} \\
\hline No & 28 & $15(53.6)$ & $13(46.4)$ & \\
\hline \multicolumn{5}{|l|}{ Histologic type } \\
\hline Endocervical & 25 & $9(36.0)$ & $16(64.0)$ & \multirow{2}{*}{0.283} \\
\hline Non endocervical & 15 & $8(53.3)$ & $7(46.7)$ & \\
\hline
\end{tabular}

There are a number of studies which have utilized the use of cell cycle regulatory genes such as P16INK4a, p21WAF1, and p27Kip1 in predicting the behavior of certain cancers such as malignant astrocytomas [23], oral squamous cell carcinomas [24], vulval carcinomas [25], and primary largecell neuroendocrine carcinoma of the parotid gland [26]. In the latter, markedly reduced expressions of $\mathrm{p} 21 \mathrm{Waf} 1$ and p27Kip1 were noted in the salivary gland cancer cells indicating highly aggressive biologic behavior [26]. Methylation of p16INK4a was seen to be correlated with gender and tumor size $(P=0.005$ and $P=0.035$, resp. $)$ in colorectal carcinoma (CRC) and could be used as a marker of poor prognosis in CRC [27]. In 224 vulvar squamous cell carcinomas stained with p16, p21, and p27, Knopp et al., noted a high expression of p16 as indicator of a better prognosis in the multivariate
TABle 7: Associations between P16INK4a expression and clinicopathologic parameter for endometrial adenocarcinoma.

\begin{tabular}{lcccc}
\hline Characteristics & $\begin{array}{c}\text { No. } \\
\text { patients }\end{array}$ & $\begin{array}{c}\text { Positive, } \\
(n=23)\end{array}$ & $\begin{array}{c}\text { Negative, } \\
n(\%) \\
(n=69)\end{array}$ & $P$ value \\
\hline $\begin{array}{l}\text { Age (years) } \\
\quad<50\end{array}$ & 28 & $5(17.9)$ & $23(82.1)$ & \\
$50-60$ & 35 & $7(20.0)$ & $28(80.0)$ & 0.148 \\
$\quad>60$ & 29 & $11(38.0)$ & $18(62.0)$ & \\
\hline FIGO stage & & & & \\
$\quad$ I & 50 & $12(24.0)$ & $38(76.0)$ & 0.809 \\
$\quad$ II-IV & 42 & $11(26.2)$ & $31(73.8)$ & \\
\hline Myometrial invasion & & & & \\
$\quad<1 / 2$ & 45 & $9(20.0)$ & $36(80.0)$ & 0.278 \\
$\quad>1 / 2$ & 47 & $14(29.8)$ & $33(70.2)$ & \\
\hline Histologic grade & & & & \\
$\quad$ G1-G2 & 62 & $11(17.7)$ & $51(82.2)$ & 0.014 \\
$\quad$ G3 & 30 & $12(40.0)$ & $18(60.0)$ & \\
\hline Postmenopausal status & & & & \\
$\quad$ Yes & 54 & $16(29.6)$ & $38(70.4)$ & 0.222 \\
No & 38 & $7(18.4)$ & $31(81.6)$ & \\
\hline Histologic type & & & & \\
$\quad$ Endometrioid & 75 & $16(21.3)$ & $59(78.7)$ & 0.888 \\
Non endometrioid & 17 & $7(41.2)$ & $10(58.8)$ & \\
\hline
\end{tabular}

analysis $(\mathrm{RR}=0.5,95 \% \mathrm{CI}=0.2-1.0)$ and less risk of developing lymph node metastasis $(\mathrm{OR}=0.3,95 \% \mathrm{CI}=0.2-0.7)$ [25]. They also noted that a high level of p 21 was significantly associated with shorter survival in patients staged FIGO I and II ( $R R=3.4,95 \% \mathrm{CI}=1.3-9.3)$. We could not find any published literature on utilizing the use of these markers on adenocarcinoma of the cervix and endometrium

In conclusion, for adenocarcinoma of the cervix, p21WAF1 expression is significantly associated with infiltration of the corpus and lymph node metastasis. p27Kip1 expression is significantly associated with lymph node invasion. The presence of lymph node metastasis is strongly associated when p16INK4a and p27Kip1 expressions are analyzed in combination. For adenocarcinoma of the endometrium, p16INK4a expression is associated with histologic grade but not histologic type. Our study shows that we could use these cell cycle markers as predictors for more aggressive subsets of adenocarcinoma of the cervix and endometrium.

\section{Acknowledgment}

The authors would like to acknowledge the Universiti Sains Malaysia for providing research grant (Account \# 1001/ PSKBP/812024) to do this study.

\section{References}

[1] S. K. Kjaer and L. A. Brinton, "Adenocarcinomas of the uterine cervix: the epidemiology of an increasing problem," Epidemiologic Reviews, vol. 15, no. 2, pp. 486-498, 1993. 
[2] H. O. Smith, M. F. Tiffany, C. R. Qualls, and C. R. Key, "The rising incidence of adenocarcinoma relative to squamous cell carcinoma of the uterine cervix in the United States-a 24year population-based study," Gynecologic Oncology, vol. 78, no. 2, pp. 97-105, 2000.

[3] F. Bray, B. Carstensen, H. Møller et al., "Incidence trends of adenocarcinoma of the cervix in 13 European countries," Cancer Epidemiology Biomarkers and Prevention, vol. 14, no. 9, pp. 2191-2199, 2005.

[4] F. Parazzini and C. La Vecchia, "Epidemiology of adenocarcinoma of the cervix," Gynecologic Oncology, vol. 39, no. 1, pp. 40-46, 1990.

[5] J. M. Elwood, P. Cole, K. J. Rothman, and S. D. Kaplan, "Epidemiology of endometrial cancer," Journal of the National Cancer Institute, vol. 59, no. 4, pp. 1055-1060, 1977.

[6] K. Garg, K. Shih, R. Barakat, Q. Zhou, A. Iasonos, and R. A. Soslow, "Endometrial carcinomas in women aged 40 years and younger: tumors associated with loss of DNA mismatch repair proteins comprise a distinct clinicopathologic subset," American Journal of Surgical Pathology, vol. 33, no. 12, pp. 1869-1877, 2009.

[7] L. T. Gien, M. C. Beauchemin, and G. Thomas, "Adenocarcinoma: a unique cervical cancer," Gynecologic Oncology, vol. 116, no. 1, pp. 140-146, 2010.

[8] E. H. Tay, M. L. Yeap, and T. H. Ho, "A 5-year review of FIGO stage IB cervical cancer in an Asian population," Singapore Medical Journal, vol. 38, no. 12, pp. 520-524, 1997.

[9] P. L. Cheah and L. M. Looi, "Carcinoma of the uterine cervix: a review of its pathology and commentary on the problem in Malaysians," Malaysian Journal of Pathology, vol. 21, no. 1, pp. 1-15, 1999.

[10] P. Tantbirojn, S. Triratanachat, P. Trivijitsilp, and S. Niruthisard, "Comparison between adenocarcinoma in both endocervical and endometrial specimens from fractional curettage and pathologic findings in subsequent hysterectomy specimens," Journal of the Medical Association of Thailand, vol. 91, no. 9, pp. 1313-1317, 2008.

[11] L. Nieuwenhuizen, M. K. Khalil, N. Venkatesh, and N. H. Othman, "Endometrial and endocervical secretion: the search for histochemical differentiation," Analytical and Quantitative Cytology and Histology, vol. 28, no. 2, pp. 87-96, 2006.

[12] S. Kamoi, M. I. AlJuboury, M. R. Akin, and S. G. Silverberg, "Immunohistochemical staining in the distinction between primary endometrial and endocervical adenocarcinomas: another viewpoint," International Journal of Gynecological Pathology, vol. 21, no. 3, pp. 217-223, 2002.

[13] D. H. Castrillon, K. R. Lee, and M. R. Nucci, "Distinction between endometrial and endocervical adenocarcinoma: an immunohistochemical study," International Journal of Gynecological Pathology, vol. 21, no. 1, pp. 4-10, 2002.

[14] L. Jiang, A. Malpica, M. T. Deavers et al., "Endometrial endometrioid adenocarcinoma of the uterine corpus involving the cervix: some cases probably represent independent primaries," International Journal of Gynecological Pathology, vol. 29, no. 2, pp. 146-156, 2010.

[15] N. Missaoui, S. Hmissa, L. Frappart et al., "p16INK4A overexpression and HPV infection in uterine cervix adenocarcinoma," Virchows Archiv, vol. 448, no. 5, pp. 597-603, 2006.

[16] C. J. Sherr, "Cancer cell cycles," Science, vol. 274, no. 5293, pp. 1672-1677, 1996.

[17] T. Abbas and A. Dutta, "P21 in cancer: intricate networks and multiple activities," Nature Reviews Cancer, vol. 9, no. 6, pp. 400-414, 2009.
[18] S. Huang, C. S. Chen, and D. E. Ingber, "Control of cyclin D1, p27(Kip1), and cell cycle progression in human capillary endothelial cells by cell shape and cytoskeletal tension," Molecular Biology of the Cell, vol. 9, no. 11, pp. 3179-3193, 1998.

[19] D. R. Ciocca, L. A. Puy, and L. C. Fasoli, "Study of estrogen receptor, progesterone receptor, and the estrogen-regulated $\mathrm{M}(\mathrm{r})$ 24,000 protein in patients with carcinomas of the endometrium and cervix," Cancer Research, vol. 49, no. 15, pp. 4298-4304, 1989.

[20] K. I. Pappa, M. Choleza, S. Markaki et al., "Consistent absence of BRAF mutations in cervical and endometrial cancer despite KRAS mutation status," Gynecologic Oncology, vol. 100, no. 3, pp. 596-600, 2006.

[21] A. Yemelyanova, R. Vang, J. D. Seidman, P. E. Gravitt, and B. M. Ronnett, "Endocervical adenocarcinomas with prominent endometrial or endomyometrial involvement simulating primary endometrial carcinomas: utility of HPV DNA detection and immunohistochemical expression of p16 and hormone receptors to confirm the cervical origin of the corpus tumor," American Journal of Surgical Pathology, vol. 33, no. 6, pp. 914924, 2009.

[22] H. Fujiwara, G. Tortolero-Luna, M. F. Mitchell, J. P. Koulos, and T. C. Wright Jr., "Adenocarcinoma of the cervix: expression and clinical significance of estrogen and progesterone receptors," Cancer, vol. 79, no. 3, pp. 505-512, 1997.

[23] T. Ohta, T. Watanabe, Y. Katayama et al., "Aberrant promoter hypermethylation profile of cell cycle regulatory genes in malignant astrocytomas," Oncology Reports, vol. 16, no. 5, pp. 957-963, 2006.

[24] E. Ishida, M. Nakamura, M. Ikuta et al., "Promotor hypermethylation of p14ARF is a key alteration for progression of oral squamous cell carcinoma," Oral Oncology, vol. 41, no. 6, pp. 614-622, 2005.

[25] S. Knopp, T. Bjørge, J. M. Nesland, C. Tropé, M. Scheistrøen, and R. Holm, "p16 ${ }^{I N K 4 a}$ and $\mathrm{p} 21^{\text {Waf } 1 / C i p 1}$ expression correlates with clinical outcome in vulvar carcinomas," Gynecologic Oncology, vol. 95, no. 1, pp. 37-45, 2004.

[26] T. Nagao, I. Sugano, Y. Ishida et al., "Primary large-cell neuroendocrine carcinoma of the parotid gland: immunohistochemical and molecular analysis of two cases," Modern Pathology, vol. 13, no. 5, pp. 554-561, 2000.

[27] I. Miladi-Abdennadher, R. Abdelmaksoud-Damak, L. Ayadi et al., "Aberrant methylation of hMLH1 and p16INK4a in Tunisian patients with sporadic colorectal adenocarcinoma," Bioscience Reports, vol. 31, no. 4, pp. 257-264, 2011. 


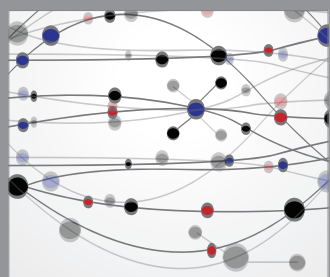

The Scientific World Journal
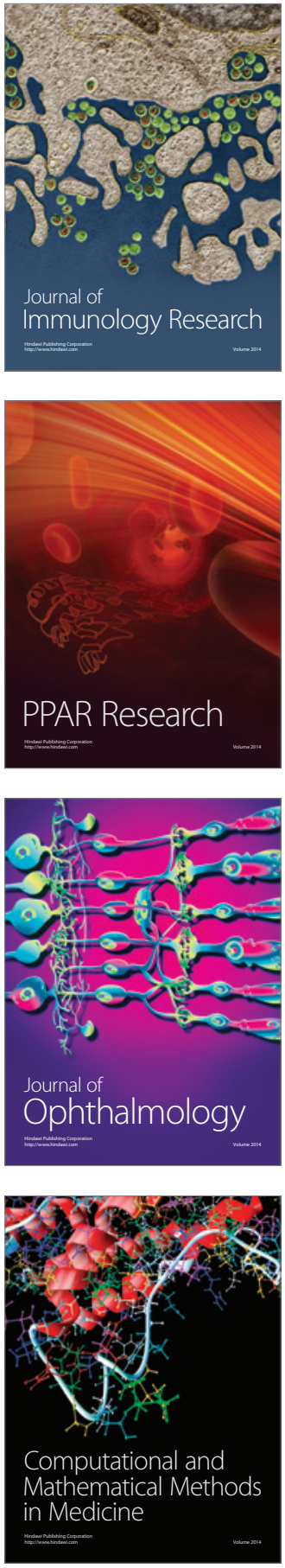

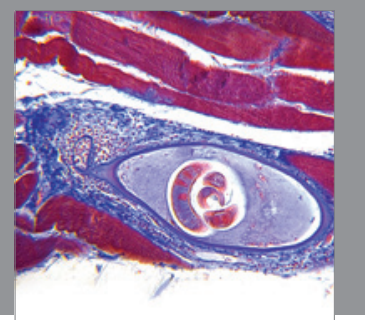

Gastroenterology

Research and Practice
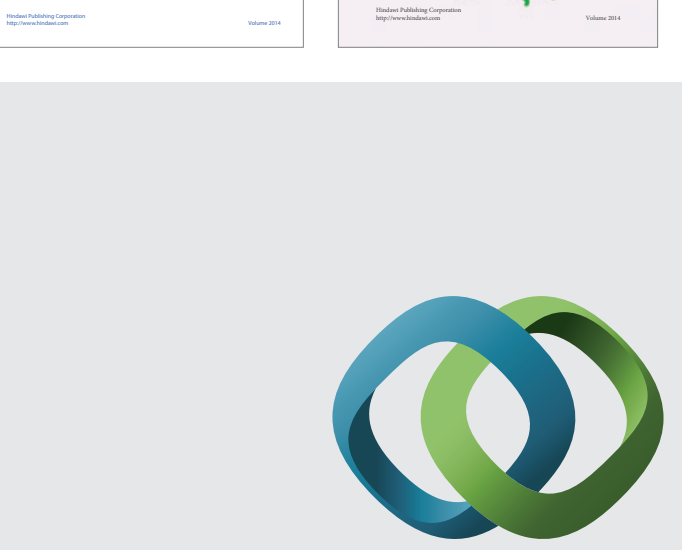

\section{Hindawi}

Submit your manuscripts at

http://www.hindawi.com
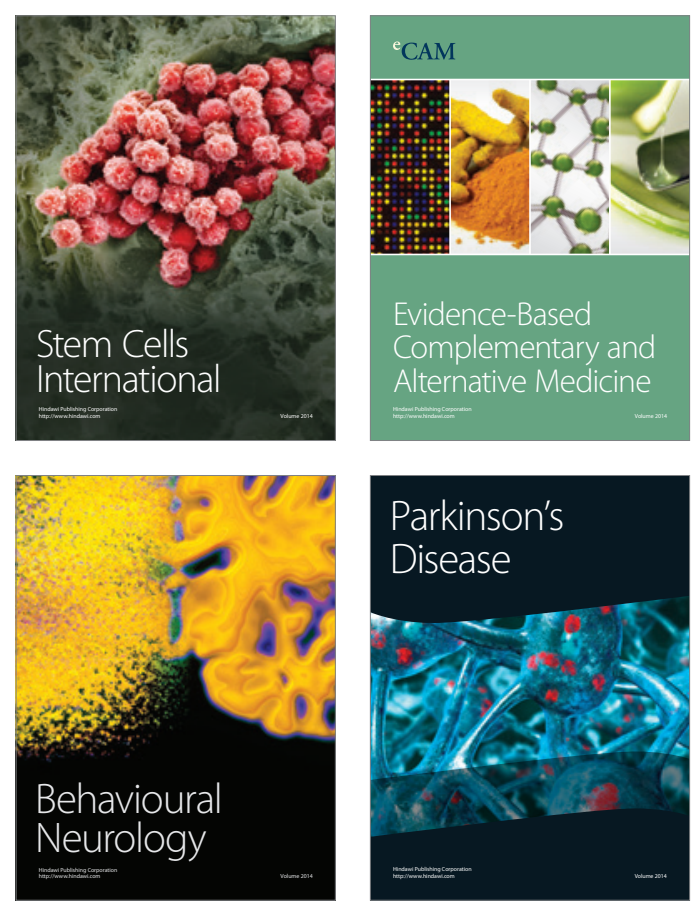

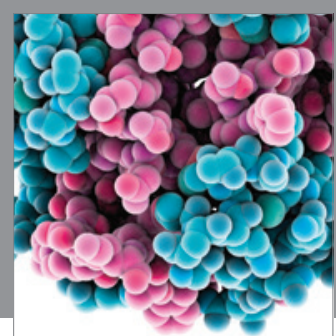

Journal of
Diabetes Research

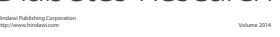

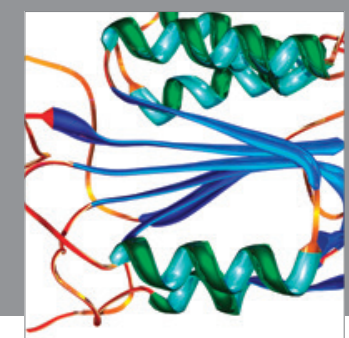

Disease Markers
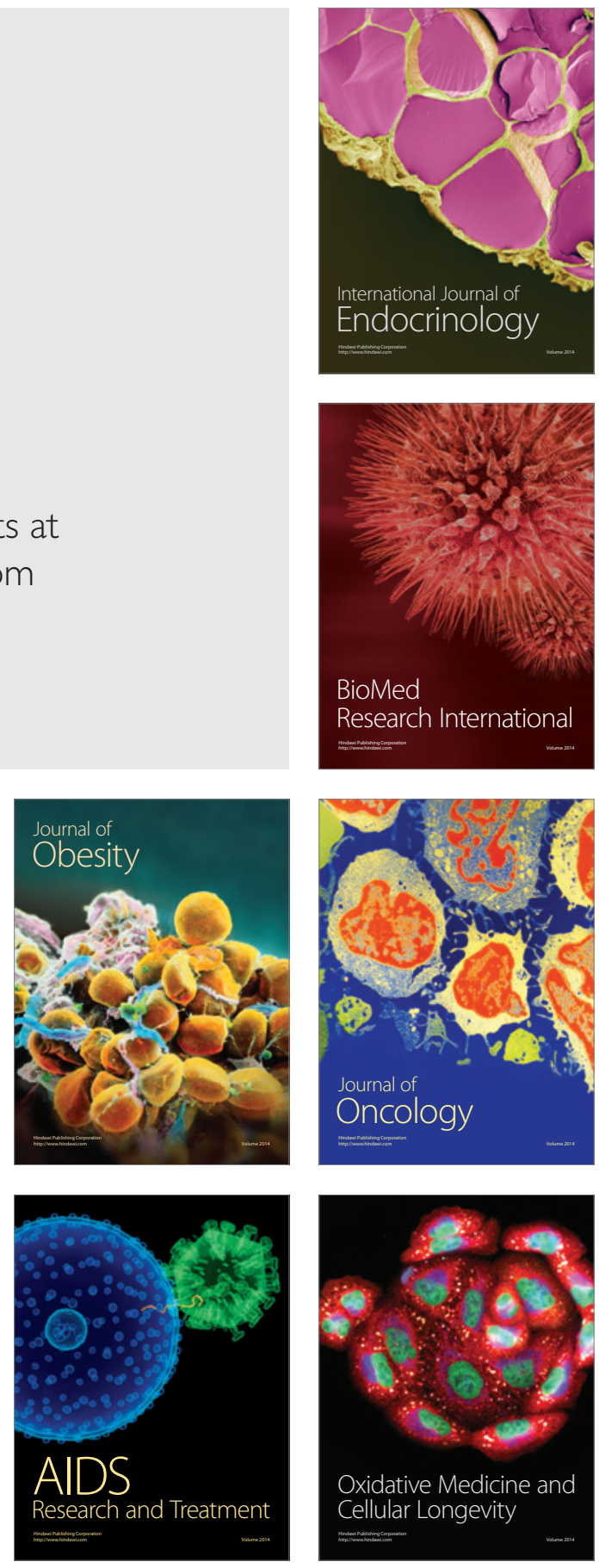